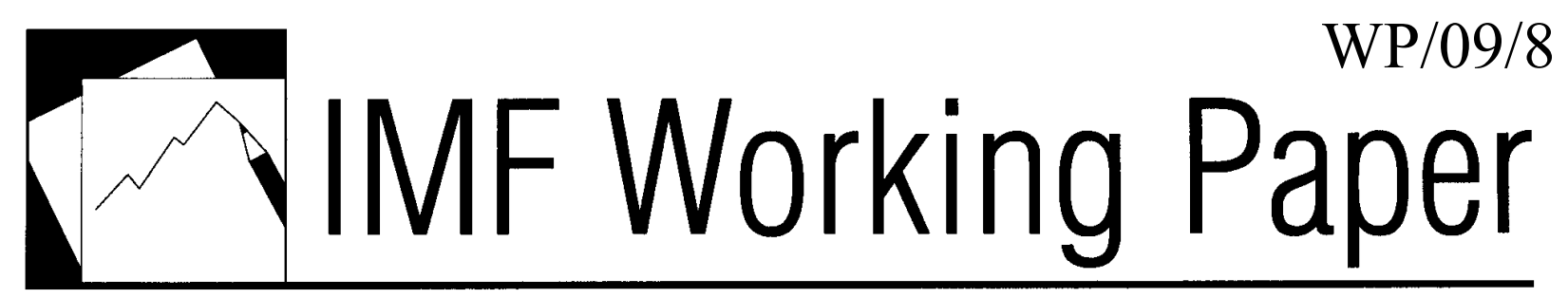

\title{
The Role for Counter-Cyclical Fiscal Policy in Singapore
}

\author{
Leif Lybecker Eskesen
}





\title{
IMF Working Paper
}

Asia and Pacific Department

\section{The Role for Counter-Cyclical Fiscal Policy in Singapore}

\author{
Prepared by Leif Lybecker Eskesen ${ }^{1}$
}

Authorized for distribution by Alessandro Zanello

January 2009

\begin{abstract}

\section{This Working Paper should not be reported as representing the views of the IMF.}

The views expressed in this Working Paper are those of the author(s) and do not necessarily represent those of the IMF or IMF policy. Working Papers describe research in progress by the author(s) and are published to elicit comments and to further debate.

Singapore's policymakers have often used fiscal policy as a counter-cyclical tool. Empirical results based on a structural autoregression framework suggest that fiscal policy can be used for demand management, although the impact may be somewhat short lived. The short-lived impact could reflect a number of factors, including the absence of credit-constrained economic agents, a high propensity to save among households, monetary focus on price stability, and leakages due to economic openness. Notwithstanding, fiscal policy should still play a key stabilizing role in the current downturn given the downside risks to growth and the vast fiscal space.
\end{abstract}

JEL Classification Numbers: C1, E62, H30

Keywords: Fiscal policy, SVAR

Author’s E-Mail Address:leskesen@imf.org

\footnotetext{
${ }^{1}$ The author would like to thank staff at the Monetary Authority of Singapore and the Ministry of Finance for their valuable comments.
} 


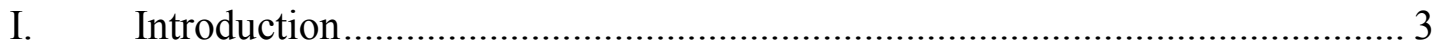

II. Cross-Country Evidence on the Counter-cyclical Role of Fiscal Policy ......... 3

III. The Counter-cyclical Role of Fiscal Policy in Singapore .............................. 5

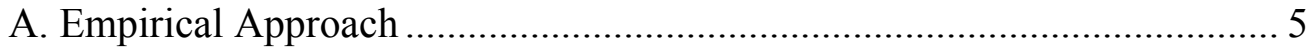

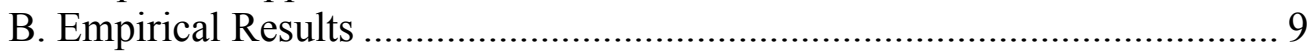

IV. The Role for Fiscal Policy in the Current Downturn .................................. 13

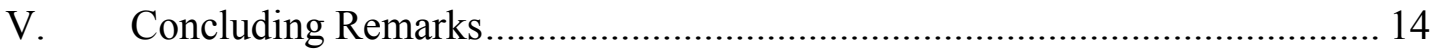

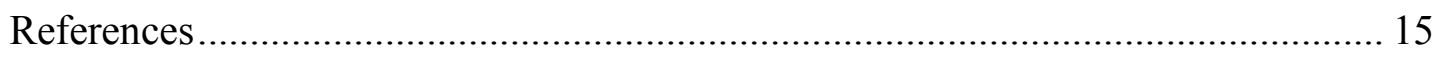

Figures

1. Fiscal Multipliers from SVAR and Macroeconometric ModelsCross-Country Evidence ............................................................................. 4

2. Fiscal Multipliers - SVAR Results............................................................ 10

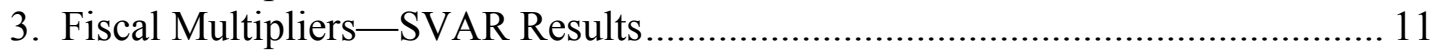




\section{INTRODUCTION}

The spillovers from the ongoing global downturn and financial turmoil has increased calls in many countries for fiscal stimulus to cushion the impact on domestic economic activity and many countries have already introduced/announced fiscal stimulus packages. In turn, this has re-ignited the long-standing debate among economists about the effectiveness of fiscal policy as a counter-cyclical tool.

Supporters of an active role for fiscal policy suggest that economies lack an efficient mechanism to return to full potential. Critics, on the other hand, argue that economic agents will offset the impact of fiscal policy on aggregate demand through changes in their saving behavior. A middle-of-the-road view holds that fiscal policy can be effective provided certain conditions hold, including sound macroeconomic fundamentals, nominal wage and price stickiness, and/or economic agents with finite horizons and liquidity constraints.

This paper analyzes empirically the effectiveness of fiscal policy in stimulating economic activity in Singapore. The empirical approach is based on a structural vector autoregression (SVAR) framework to derive fiscal multipliers. In this context, the paper also discusses the role for fiscal policy in addressing the current economic downturn.

The paper is organized as follows: Section II looks at the cross-country evidence on the counter-cyclical role of fiscal policy; Section III presents the empirical approach and results for Singapore; Section IV discusses the role for fiscal policy in the current downturn; and Section V presents concluding remarks.

\section{Cross-Country Evidence on the Counter-CyClical Role of Fiscal Policy}

The question of the effectiveness of fiscal policy is ultimately empirical. There is a vast literature on this topic. Studies generally support the role for counter-cyclical measures, but evidence on the size of fiscal multipliers varies with the analytical approach:

- $\quad$ Event studies give mixed results. The 2001 income tax rebates in the United States are generally considered to have been effective in boosting domestic demand, although the impact on output was relatively small with multipliers well below 1 (Shapiro and others, 2002, 2003). The 1995 stimulus package in Japan is estimated to have been successful, but it did not have a lasting impact on economic activity (Posen (1998), Mühleisen (2000)). Finland's response to the 1991 output shock, by letting automatic stabilizers operate fully, is considered to have been largely ineffective because it raised concerns about fiscal sustainability (Corsetti and Roubini, 1996). IMF, World Economic Outlook (October 2008) provide evidence that the size of public debt and composition of fiscal stimulus could be important determinants of the effect of fiscal policy. 


\section{Figure 1. Fiscal Multipliers from SVAR and Macroeconometric Models-Cross-Country Evidence}

Fiscal Multipliers from SVAR Models: 1 Percent of GDP Tax Cut (Cumulative GDP response at 12 quarters over different time periods)

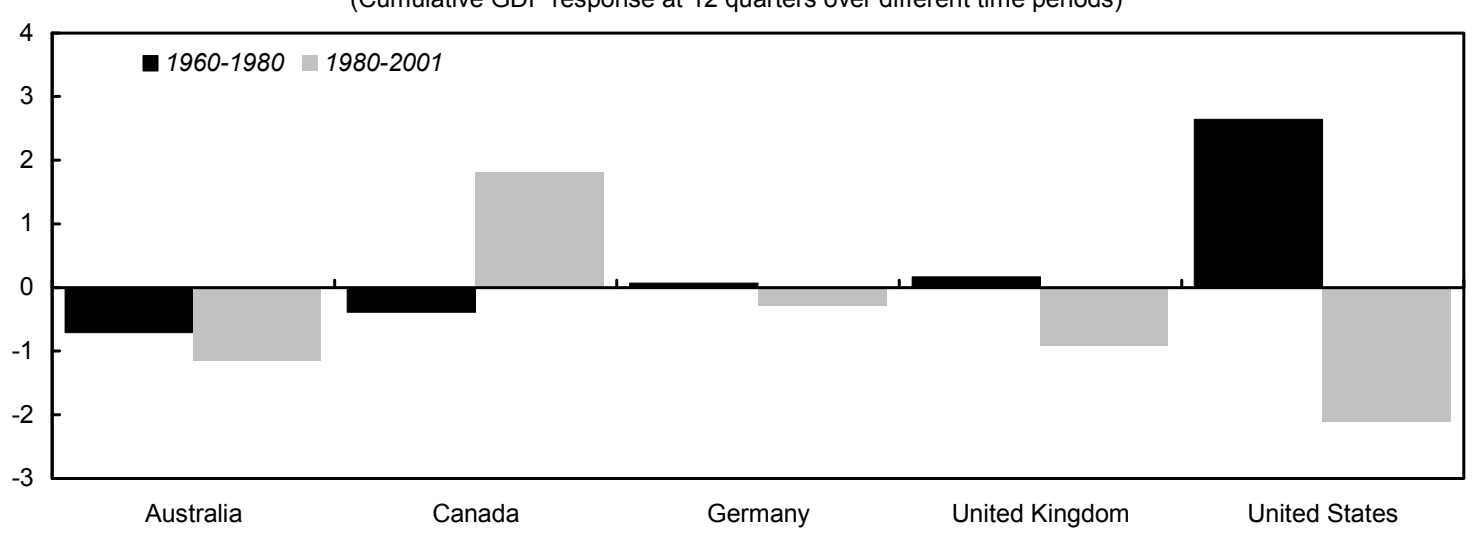

Fiscal Multipliers from SVAR Models: 1 Percent of GDP Increase in Spending

(Cumulative GDP response at 12 quarters over different time periods)

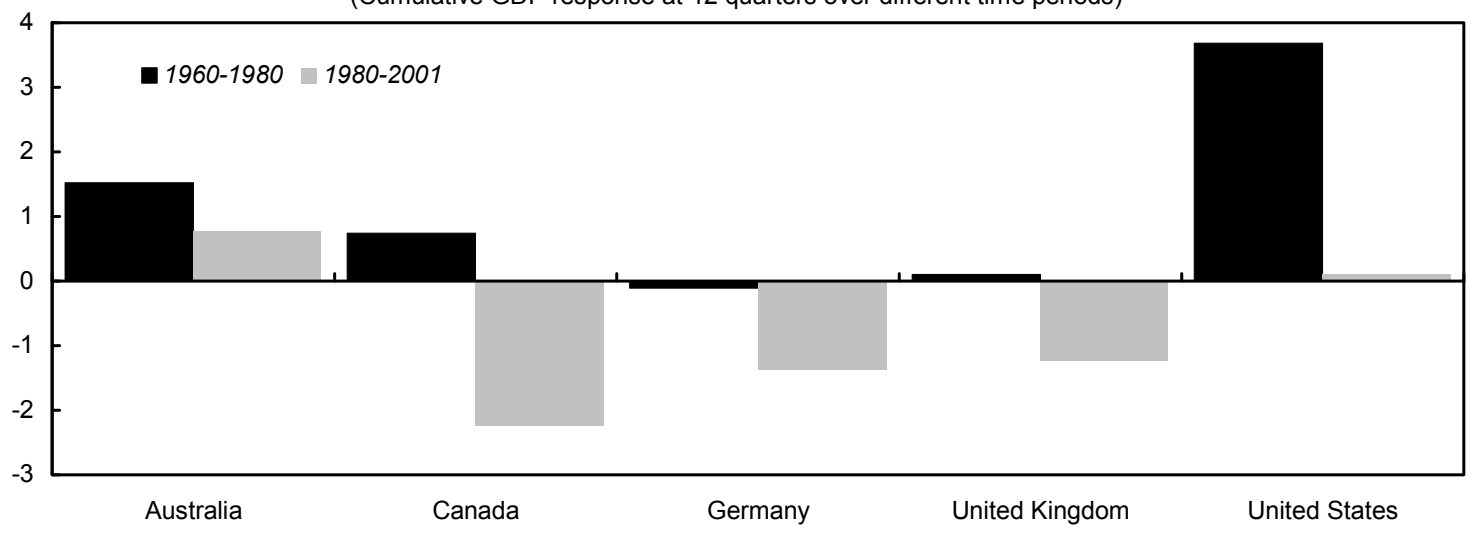

Fiscal Multipliers from Macroeconometric Models: 1 Percent of GDP Spending Increase (Cumulative GDP response at 4 and 8 quarters)

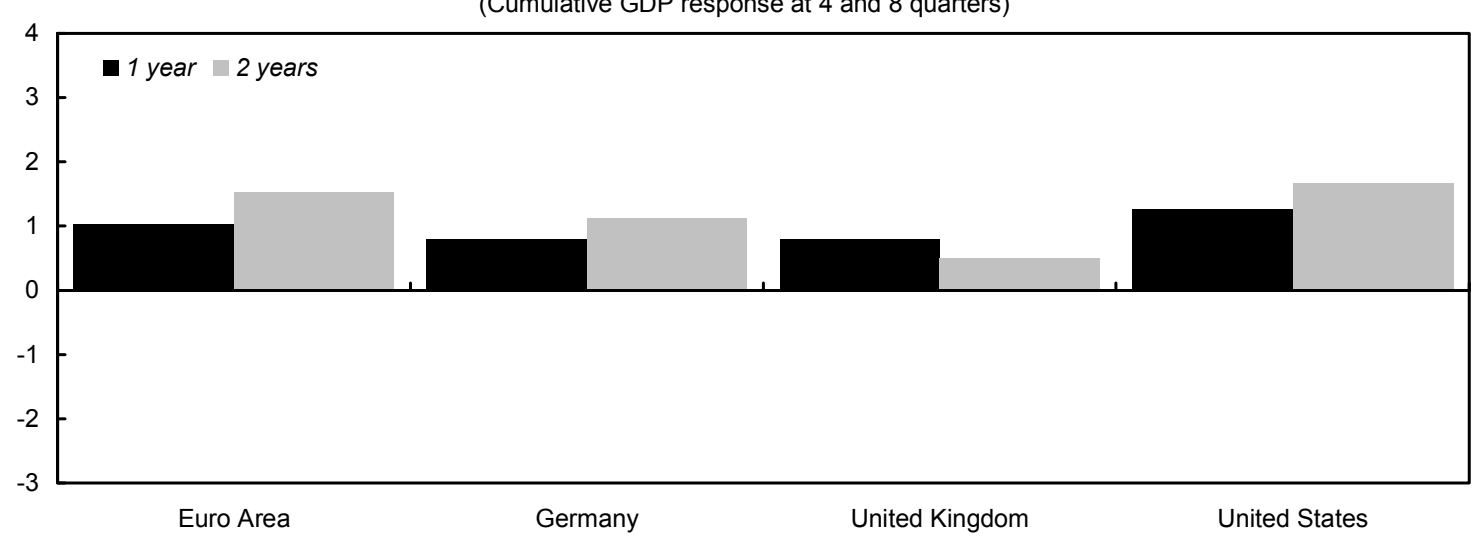

Source: Perotti (2005). 
- $\quad$ Studies on advanced economies using vector autoregressive (VAR) methods conclude that fiscal multipliers have declined over time and, in some cases, may even have been negative (see Perotti (2005) for an overview). These results (Figure 1), which differ widely across countries, likely reflect: (i) increasing leakage through the trade channel due to higher openness of economies; (ii) a decline in the share of liquidity constrained households due to better access to credit; and (iii) a sharper focus of monetary policy on price stability.

- $\quad$ Estimates from macro models, on the other hand, show that fiscal policy can be quite effective (Figure 1). Impact multipliers are in the range of 0.3 to 1.2 percent and expenditure measures appear to have a larger effect than tax measures (Hemming and others 2002, Botman 2006). IMF, World Economic Outlook (October 2008) find that government investment has the largest impact on economic activity and inflation. However, the size of the estimated multipliers depends on assumptions, among others, about the monetary regime, labor supply elasticities, and the pervasiveness of liquidity constraints.

Generally, the cross-country evidence suggests that the success of fiscal policy is contingent on a number of factors. First, the fiscal response needs to be well-timed. This will, in particular, reinforce the effectiveness of fiscal policy in countries with short implementation lags and/or large automatic stabilizers. Second, strong fundamentals, including macroeconomic stability and fiscal sustainability, will strengthen multiplier effects by lowering any possible offsets from precautionary savings. Finally, fiscal measures need to be well-targeted to ensure the largest possible demand impact.

\section{The Counter-Cyclical Role of Fiscal Policy in Singapore}

Fiscal policy in Singapore has often been used to counter adverse external shocks. In the aftermath of the Asian crisis (1998), the bursting of the tech-bubble (2001), and the SARS shock (2003), the authorities relied on fiscal measures to help cushion the impact on economic activity and vulnerable groups. The fiscal counter-measures focused on relief for both businesses and households, including through tax incentives, tax credits, transfer payments, and various rebates on housing and utilities. To cushion the impact of the ongoing economic slowdown, the FY 2008/09 budget and supplementary measures focused on improving competitiveness and supporting household disposable income, including through tax incentives, a one-off personal income tax rebate, and targeted cash transfers. The FY 2009/10 budget will be presented in January 2009 and is expected to include a number of counter-cyclical measures to address the economic downturn.

\section{A. Empirical Approach}

VAR methods are standard in monetary policy analysis, but have only more recently been applied to study the effectiveness of fiscal policy. This paper applies a SVAR framework based on the methodology developed in Blanchard and Perotti (2002). Intuitively, this 
methodology utilizes the "inside" lags of fiscal policy to identify discretionary structural fiscal shocks and their impact on economic activity: ${ }^{2}$

- $\quad$ Assuming that discretionary fiscal decisions take time to implement (because of political and legislative requirements), the short-term (i.e., within one quarter) reaction of fiscal variables to current economic developments only reflect "automatic" responses defined by existing laws and regulations.

- $\quad$ Fiscal developments adjusted for these automatic/cyclical responses are, therefore, assumed to represent discretionary structural fiscal policy shocks.

- In simulations, these structural shocks are used to quantify the response of real economic variables to fiscal policy. In the case of Singapore, the focus is on private domestic demand, in part to abstract from first-order leakages.

\section{Specification of SVAR model}

The SVAR approach starts from the basic reduced form VAR specification:

$$
z_{t}=\Gamma(L) z_{t-1}+u_{t}
$$

where $z_{t}$ is a $n \mathbf{x} 1$ vector of endogenous variables, $\Gamma(L)$ is a $n \mathbf{x} n$ matrix of lag polynomials in the lag operator $L$, and $u_{t}$ is a $n \mathbf{x} 1$ vector of reduced-form innovations, which are independent and identically distributed. As it is standard in the literature on structural VARs, the relation between the reduced-form innovations, $u_{t}$, and the objects of ultimate interest, the structural shocks, $v_{t}$, can be represented as:

$$
A u_{t}=B v_{t}
$$

where the $n \mathbf{x} n$ matrices $A$ and $B$, respectively, describe (i) the instantaneous relation between the variables and (ii) the linear relationship between the reduced form residuals and the structural shocks. The structural shocks are assumed to be independently and identically distributed with covariance matrix equal to the identity one. The structural form of the VAR can be obtained by multiplying (1) by $A$ and using the relation defined in (2):

$$
A z_{t}=A \Gamma(L) z_{t-1}+A u_{t}=A \Gamma(L) z_{t-1}+B v_{t}
$$

Solving (3) for $z_{t}$ yields the structural specification:

$$
z_{t}=[I-\Gamma(L) L]^{-1} A^{-1} B v_{t}
$$

\footnotetext{
${ }^{2}$ Inside lags refer to the lag between the decision to take measures and their actual implementation.
} 
Where $I$ is a $n \mathbf{x} n$ identity matrix.

In the simplest specification used in this study, $z_{t}=\left[\begin{array}{lll}y_{t} & e_{t} & r_{t}\end{array}\right]$ consists of three variables: real private domestic demand, $y_{t}$; real government expenditure (consumption and investment), $e_{t}$; and real current government revenue, $r_{t}{ }^{3}$ Given the assumption that discretionary fiscal decisions take more than one quarter to implement, quarterly seasonally adjusted data (from 1990Q1 to 2007Q4) are used in order to identify the structural shocks. The VAR is estimated in log levels with a constant, time dummies, and G7 growth added as exogenous explanatory variables. The number of lags chosen is five as suggested by Akaike and other information criteria. $^{4}$

\section{Identification of structural shocks}

The identification of the structural shocks and estimation of fiscal multipliers basically proceeds in four steps. In the first step, the VAR specified in (1) is estimated, yielding the reduced form residuals $u_{t}=\left[\begin{array}{lll}u_{t}^{y} & u_{t}^{e} & u_{t}^{r}\end{array}\right]$. As suggested by Perotti (2005), the innovations $u_{t}^{e}$ and $u_{t}^{r}$ can be thought of as linear combinations of three types of shocks:

(i) the automatic or cyclical response of expenditures and revenues to innovations in private domestic demand; (ii) the systematic response of fiscal policy to same-period macro shocks; and (iii) discretionary structural fiscal shocks. This can be represented as follows:

$$
\begin{aligned}
& u_{t}^{y}=\alpha_{e}^{y} u_{t}^{e}+\alpha_{r}^{y} u_{t}^{r}+v_{t}^{y} \\
& u_{t}^{e}=\alpha_{y}^{e} u_{t}^{y}+\beta_{r}^{e} v_{t}^{e}+v_{t}^{e} \\
& u_{t}^{r}=\alpha_{y}^{r} u_{t}^{y}+\beta_{e}^{r} v_{t}^{e}+v_{t}^{r}
\end{aligned}
$$

where $v_{t}^{e}$ and $v_{t}^{r}$ are the (mutually uncorrelated) structural shocks to government expenditure and revenues, respectively, that we seek to identify. Since discretionary fiscal decision are assumed to be implemented with a lag of more than one quarter (as mentioned above), systematic discretionary responses to macro shocks (i.e., (ii)) can be ignored, which is key for the identification of the structural shocks, (iii). As a consequence, the coefficients $\alpha_{y}^{e}$ and $\alpha_{y}^{r}$ in (6) and (7) only capture the automatic/cyclical response of fiscal variables to changes in economic activity.

\footnotetext{
${ }^{3}$ Quarterly data for special transfers were unfortunately not available and are, therefore, not included in the expenditure data.

${ }^{4}$ The models specified in this paper are generally robust to alternative specifications and residuals do not appear to suffer from autocorrelation. Tests for normality of error terms suggest there is no skewedness, but there may be kurtosis.
} 
Given that the reduced form residuals are correlated with the structural shocks, it is necessary to apply further restrictions to identify the coefficients $\alpha_{y}^{e}$ and $\alpha_{y}^{r}$. For instance, ordinary least square regression of $u_{t}^{e}$ on $u_{t}^{y}$ in equation (6) would not generate consistent estimates of $\alpha_{y}^{e}$. Therefore, in order to identify the system, external (nonsystem generated) estimates of $\alpha_{y}^{e}$ and $\alpha_{y}^{r}$ are used. ${ }^{5}$ With these, the cyclically adjusted fiscal shocks, $u_{t}^{e, a d j .}$ and $u_{t}^{r, a d j .}$, can be calculated, which constitutes the second step of the identification procedure:

$$
\begin{aligned}
& u_{t}^{e, a d j .} \equiv u_{t}^{e}-\alpha_{y}^{e} u_{t}^{y}=\beta_{r}^{e} v_{t}^{r}+v_{t}^{e} \\
& u_{t}^{r, a d j .} \equiv u_{t}^{r}-\alpha_{y}^{r} u_{t}^{y}=\beta_{e}^{r} v_{t}^{e}+v_{t}^{r}
\end{aligned}
$$

In the third step, the structural fiscal shocks are identified. Assuming that structural revenue shocks have no impact on structural spending shocks (i.e., $\left.\beta_{r}^{e}=0\right),(8)$ reduces to

$$
u_{t}^{e, a d j}=v_{t}^{e}
$$

The structurally adjusted expenditure shocks are effectively assumed equal to the cyclically adjusted expenditure shocks. These have already been calculated and can be used in (9) to estimate the response of (cyclically adjusted) revenues to structural expenditure shocks, $\beta_{e}^{r}$, using simple ordinary least square regressions.

In the fourth and final step, the coefficients $\alpha_{e}^{y}$ and $\alpha_{r}^{y}$ in the equation for private domestic demand residuals, (5), can be determined using the structural uncorrelated fiscal shocks $v_{t}^{e}$ and $v_{t}^{r}$ as instruments for $u_{t}^{e}$ and $u_{t}^{r}$, respectively. Combined, the four steps allow us to estimate the $A$ and $B$ matrices presented in (2):

$$
\mathrm{A}=\left[\begin{array}{ccc}
1 & -\alpha_{e}^{y} & -\alpha_{r}^{y} \\
-\alpha_{y}^{e} & 1 & 0 \\
-\alpha_{y}^{r} & 0 & 1
\end{array}\right]
$$

\footnotetext{
${ }^{5}$ For Singapore, the elasticity of expenditures with respect to changes in economic activity is assumed to be close to zero within the quarter, as commonly assumed in many other empirical studies. The elasticity of revenues is estimated at around $1 / 2$ percent within the quarter. The relatively low number partly reflects that corporate taxes are based on past year's rather than contemporaneous earnings, leaving taxes less responsive to contemporaneous changes in economic activity. While the parameterization is plausible, the magnitude has implications for the estimated multipliers.
} 


$$
\mathrm{B}=\left[\begin{array}{ccc}
1 & 0 & 0 \\
0 & 1 & 0 \\
0 & \beta_{e}^{r} & 1
\end{array}\right]
$$

Dividing (2) by A it can be shown that the reduced form residuals are linear combinations of the orthogonal structural shocks of the form:

$$
u_{t}=\left[\begin{array}{ccc}
1 & -\alpha_{e}^{y} & -\alpha_{r}^{y} \\
-\alpha_{y}^{e} & 1 & 0 \\
-\alpha_{y}^{r} & 0 & 1
\end{array}\right]^{-1}\left[\begin{array}{ccc}
1 & 0 & 0 \\
0 & 1 & 0 \\
0 & \beta_{e}^{r} & 1
\end{array}\right]\left[\begin{array}{c}
v_{t}^{y} \\
v_{t}^{e} \\
v_{t}^{r}
\end{array}\right]
$$

With this, impulse responses are computed using Monte Carlo simulations based on 10000 replications. The results are discussed in the next section.

\section{B. Empirical Results}

Empirical results suggest that discretionary fiscal policy can have an impact on private domestic demand and play a role as a counter-cyclical tool, although the impact drops off quickly and eventually turns negative (Figure 2 and 3). However, the estimated impulses are generally not significant past the fourth quarter and the impulses beyond this should, consequently, be interpreted with caution. Moreover, the results are sensitive to the estimated cyclicality of expenditures and revenues (i.e., elasticities with respect to macroeconomic variables). Indeed, the near-term impact of revenue changes would almost double if the elasticity was 0.75 rather than the 0.5 used for this exercise. Even so, the response would still remain somewhat short-lived.

The short-lived cumulative impact may reflect a number of factors, including:

- The limited number of credit-constrained households, leading to a somewhat lower consumption response, on the margin, to changes in disposable incomes;

- A high propensity to save among households - possibly, in part, reflecting the lack of a more comprehensive social safety net;

- The use of nonbudgetary measures to stimulate economic activity, including through changes in contributions to the mandatory public savings scheme (CPF). These are not captured in the fiscal variables used in this study;

- $\quad$ Strong monetary focus on price stability, which may partly offset the effect of a fiscal stimulus;

- $\quad$ Significant leakages through trade as well as remittances (nonresident workers account for around 30 percent of the labor force), which may weaken the dynamic interrelations between domestic demand components. 
Figure 2. Singapore: Fiscal Multipliers in Singapore-SVAR Results

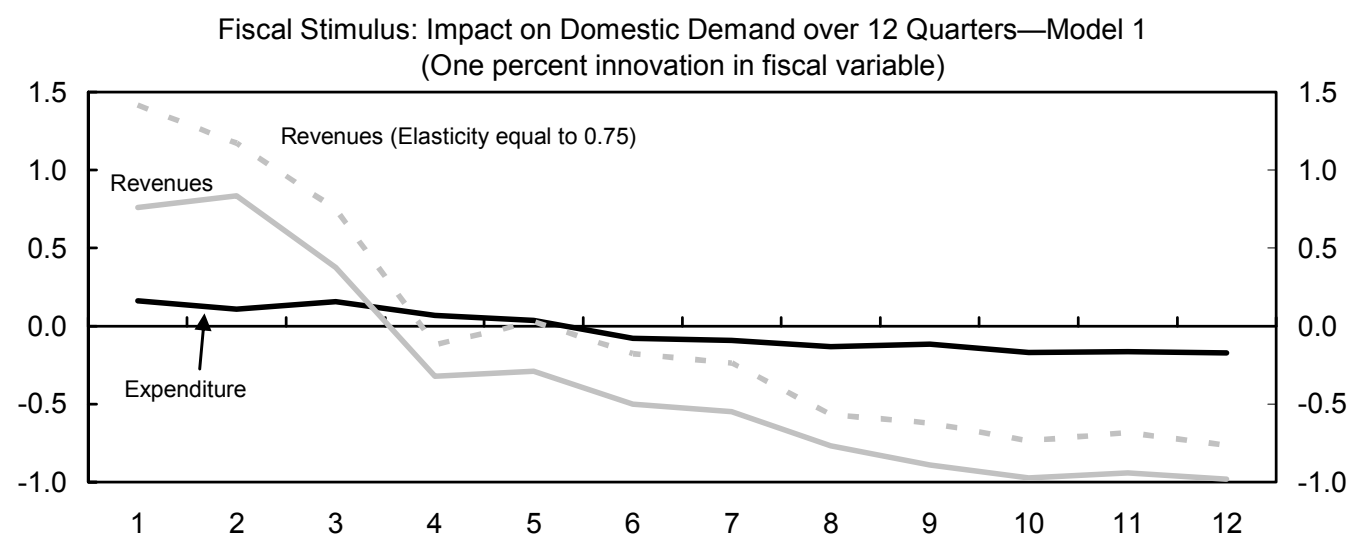

Fiscal Stimulus: Impact on Domestic Demand over 12 Quarters-Model 2

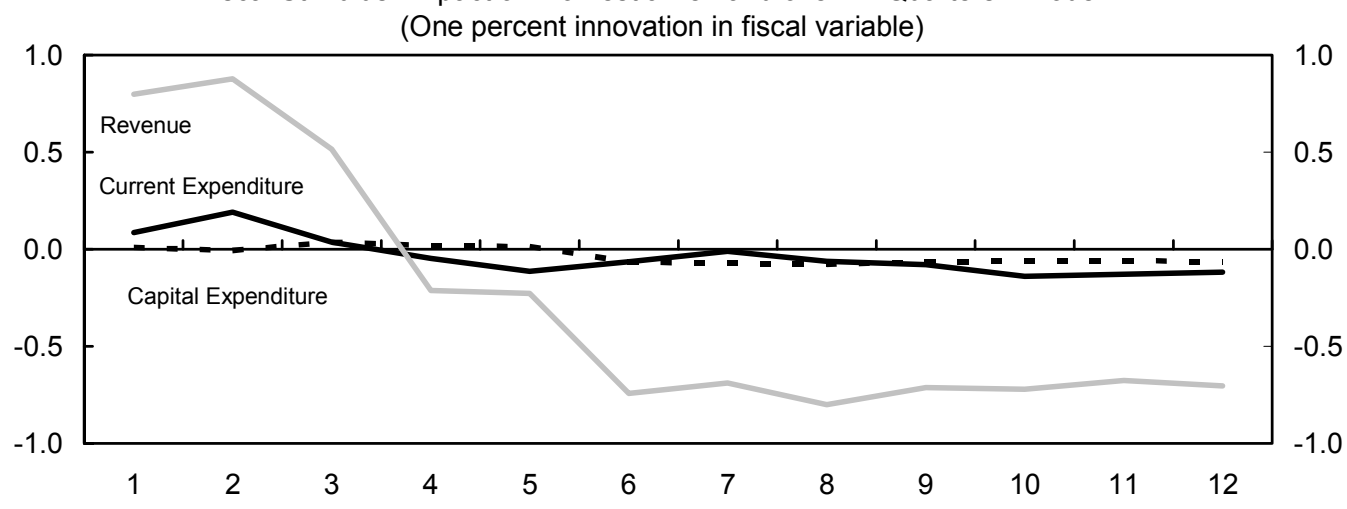

Fiscal Stimulus: Impact on Domestic Demand and Inflation over 12 Quarters—Model 3

(One percent innovation in fiscal variable)
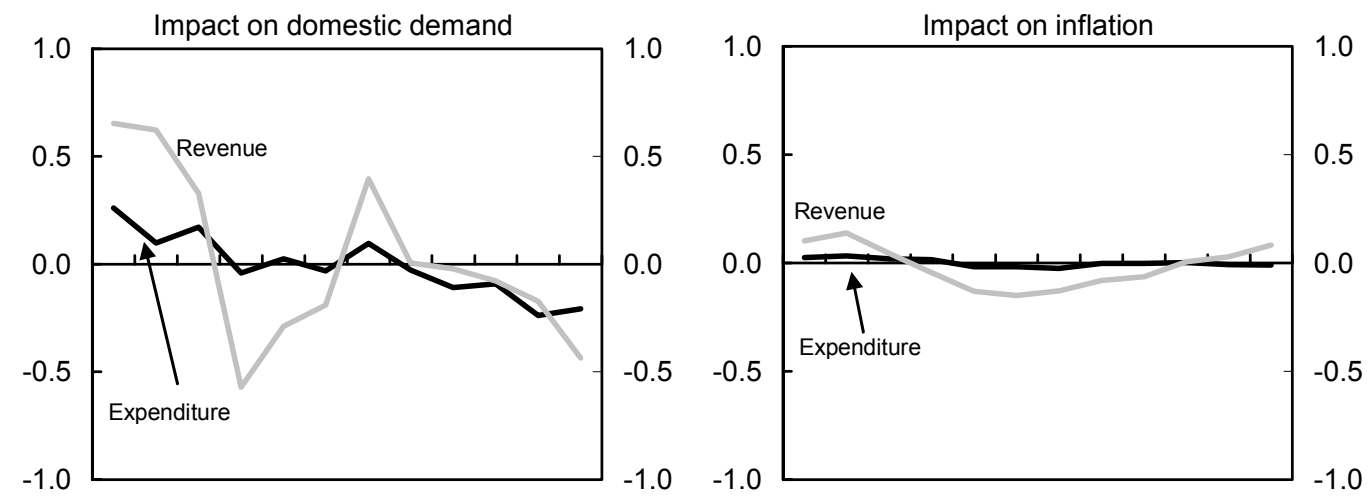

$\begin{array}{lllllllllllll}1 & 2 & 3 & 4 & 5 & 6 & 7 & 8 & 9 & 10 & 11 & 12\end{array}$

$\begin{array}{lllllllllllll}1 & 2 & 3 & 4 & 5 & 6 & 7 & 8 & 9 & 10 & 11 & 12\end{array}$

Source: Staff estimates 
Figure 3. Fiscal Multipliers in Singapore-SVAR Results

Fiscal Stimulus: Cumlative Impact on Real Demand-Model 1 (S\$ 1 innovation in fiscal variable)

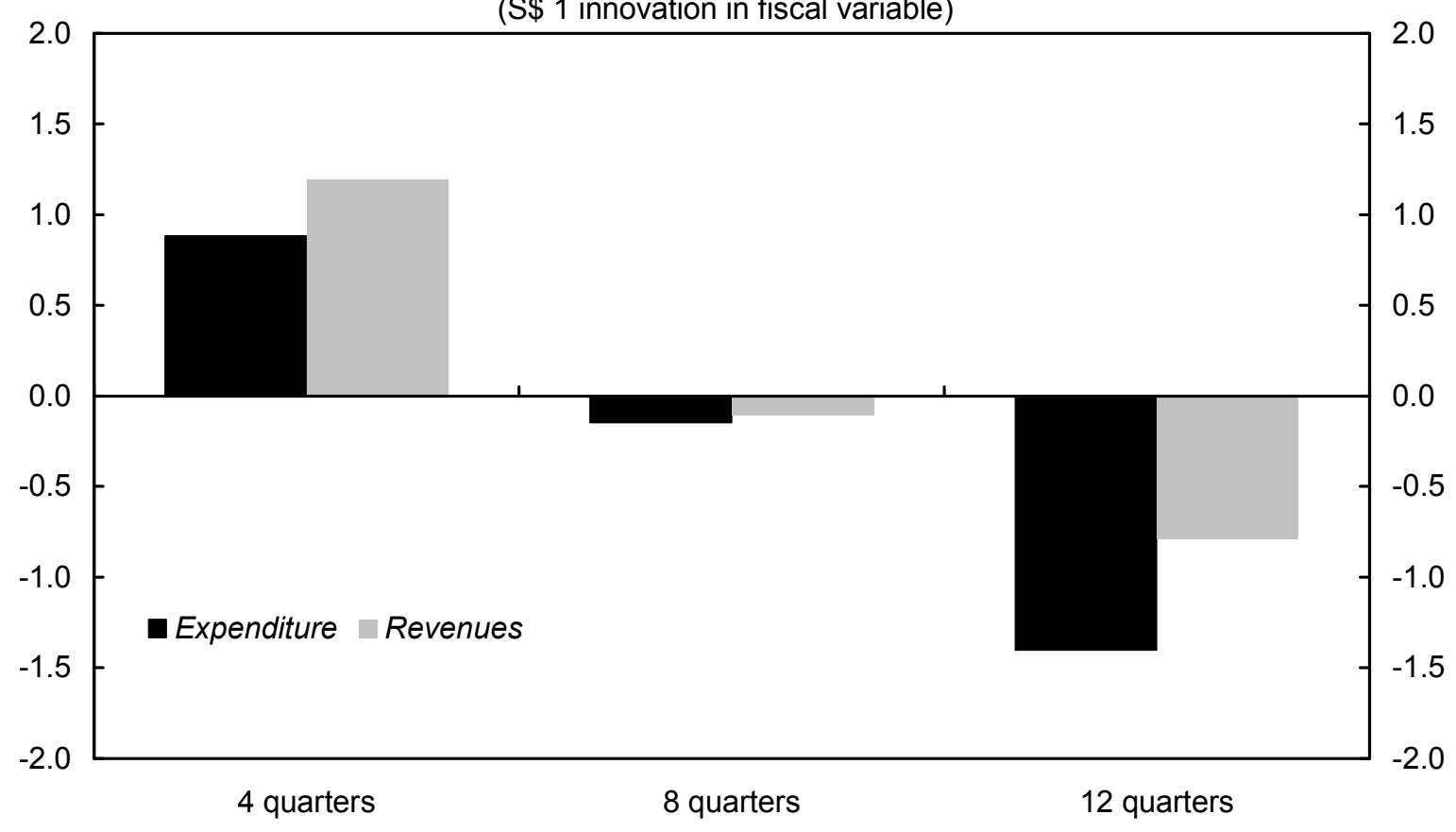

Fiscal Stimulus: Cumlative Impact on Real Demand-Model 2

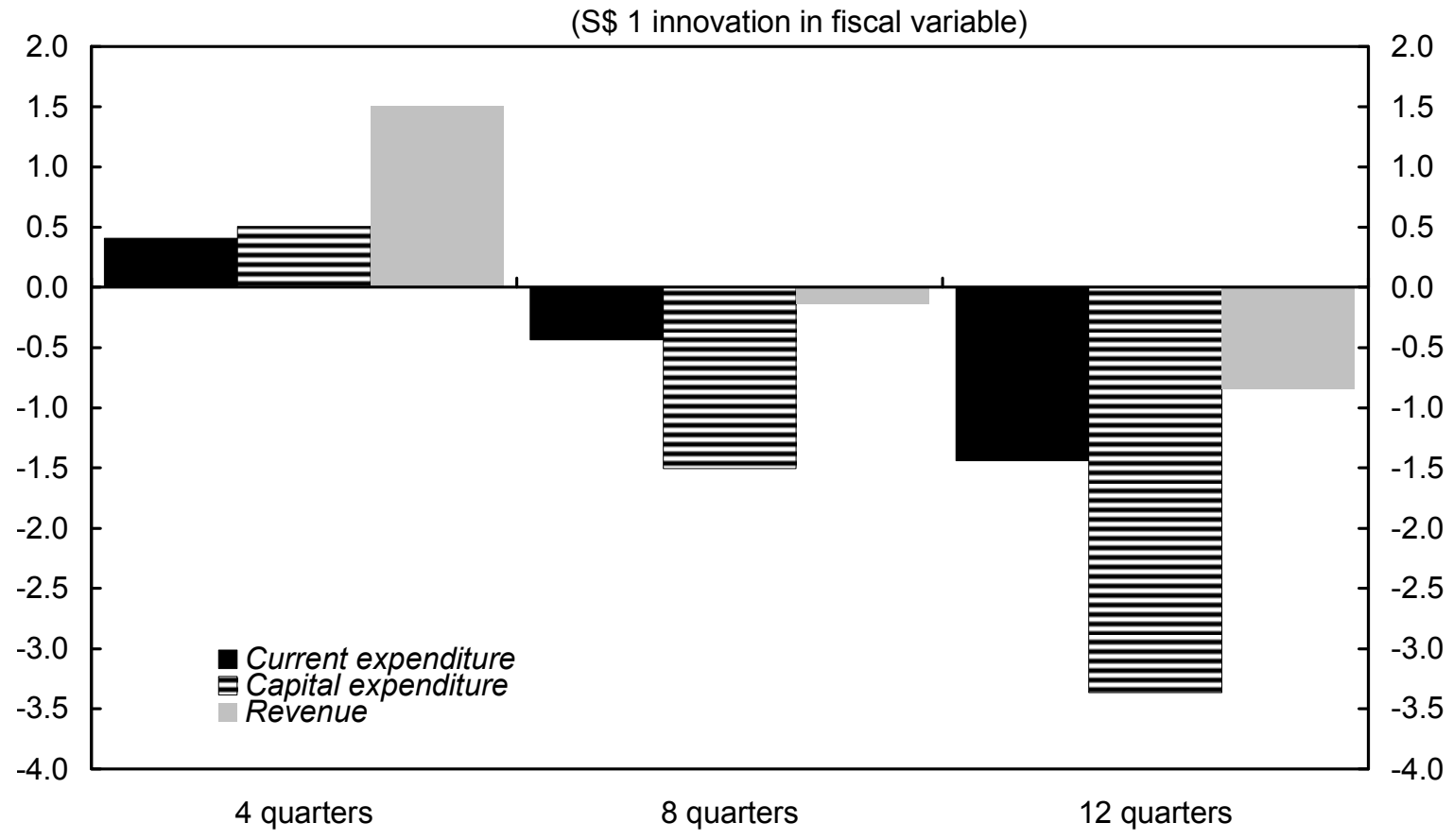

Source: Staff estimates.

Note: The cumulative multiplier equals the ratio of the cumulative response of real private demand to the cumulative response of the real fiscal variable shocked. 
Among fiscal shocks, discretionary changes in revenues are estimated to have a somewhat larger impact on private demand compared to changes in expenditure (Figure 2). However, this difference is much smaller when revenue and expenditure measures are compared on a dollar for dollar basis (Figure 3), given the relatively larger size of revenues. ${ }^{6}$

The somewhat larger revenue multipliers may be explained, inter alia, by the following two factors:

- $\quad$ First, counter-cyclical measures have often focused on easing the corporate cost burden through tax measures. At the same time, the government has frequently focused discretionary spending measures on strengthening household saving, including for education, medical care, and retirement. Moreover, the impact of household targeted measures may be smaller due to the relatively high precautionary savings-preference of Singaporean households.

- $\quad$ Second, a narrow definition of government expenditure is used in this study, excluding some income transfers programs for lack of quarterly data. Indeed, excluded cash transfers such as the "Growth Dividends" distributed in 2008 (and previously), may well have a measurable impact on domestic demand not captured in these simulation exercises, especially considering the direct nature and targeting of these transfers.

Among expenditure components, the simulations show that a one percent change in government current spending provides more impetus to private domestic demand than a one percent change in public investment (Figure 2). However, factoring in the relatively larger size of government consumption compared to government investment, their dollar for dollar multipliers are more or less of the same magnitude (Figure 3). That being said, the estimates for investment multipliers are generally not highly significant.

By aggregate demand component, the estimated impulse response functions suggest fiscal policy has a larger impact on private investment than on private consumption (not shown here). This may in part reflect the government's strategy, mentioned above, of focusing stimulus measures on easing the cost burden of businesses, while often seeking to bolster household savings.

A fiscal expansion has a positive but limited impact on inflation. The largest impact is related to changes in taxes, which is consistent with the estimated larger impact on private demand (and hence inflation pressures) from changes in government revenues. Government spending, on the other hand, does not appear to have a significant impact on prices. The impact on

\footnotetext{
${ }^{6}$ Figure 2 shows the impact from 1 percent innovations in the fiscal variable, while Figure 3 shows the impact from $\mathrm{S} \$ 1$ innovations.
} 
inflation, which initially is positive and then turns negative, would appear to lessen the demand impact in the short term and support it later on as inflation recedes.

The analysis presented in this section could be expanded in a number of ways. It could be useful in future research to analyze the impact of more disaggregated fiscal measures on private demand and its sub-components, which could help strengthen fiscal design. A study of the impact of income transfers based on a complete data set would be desirable. Finally, the results could be subjected to further sensitivity analysis. All these potential extensions remain on the research agenda.

\section{The Role for Fiscal Policy in the Current Downturn}

Notwithstanding the relatively short-lived impact of fiscal stimulus suggested by the SVAR model presented above, fiscal policy should still play a key stabilizing role in the current downturn, especially in light of the heightened uncertainty about the depth and duration of the downturn. Moreover, Singapore's large fiscal reserves and structural surplus position provides the authorities ample room to use counter-cyclical fiscal policy. This room has now expanded with the implementation of a constitutional amendment to the spending framework, which allows the government to each year tap a larger share of the returns from the fiscal reserves invested by the country's two sovereign wealth funds (the Government of Singapore Investment Corporation and Temasek Holdings).

Given Singapore's relatively small automatic stabilizers, a counter-cyclical response would have to rely on discretionary measures. ${ }^{7}$ However, Singapore benefits from short fiscal implementation lags, which allow for a fast discretionary response to changing economic conditions. To ensure effectiveness of discretionary policy measures, the fiscal stimulus should be timely (i.e., presented with the upcoming budget), significant (given considerable downside risks), and prolonged (in light of the protracted nature of the slowdown). Moreover, it will be important for the authorities to signal willingness to do more if needed to help allay uncertainties, thereby lessening precautionary saving motives of corporates and households and safeguarding the effectiveness of the fiscal measures introduced.

Although the results presented in this paper point to a somewhat stronger impact from revenue measures, the likely prolonged duration of the downturn and the elevated level of uncertainty suggest a diversified stimulus package of both revenue and expenditure measures could be considered. There is no "magic formula" for effective fiscal stimulus, but the international experience suggest a number of broad lessons, including the following:

- $\quad$ Revenue measures: Personal income tax credits could be effective through fast and targeted distribution. A lowering of corporate income, dividend, and capital gains

\footnotetext{
${ }^{7}$ Singapore does not have a comprehensive unemployment benefit scheme and corporate taxes are assessed based on previous year's income.
} 
taxation is often effective in more normal circumstances, but may be less effective in the current weak economic environment given the likely significant cyclical decline in the relevant tax bases. To foster inter-temporal substitution, a possibility would be to introduce a temporary tax credit on new investment and, possibly, a temporary reduction in consumption taxes. However, the latter option is not without limitations: (i) it is not as well targeted as some other options; (ii) it may not boost consumers' disposable incomes if prices remain unchanged; and (iii) in an environment of waning confidence such as the current one, it may not be enough to encourage consumption.

- $\quad$ Expenditure measures: Targeted cash transfers could quickly be disbursed and support the neediest with the highest propensity to consume. Taking steps to further expand social safety nets could also help lessen the precautionary savings of households. However, such measures take time to implement and could serve more as a medium term objective. Frontloading existing investment projects and stepping up maintenance spending could have a more immediate impact on demand.

\section{Concluding REMARKS}

Singapore's policymakers have often relied on fiscal policy to counter the impact of adverse external shocks. Empirical results based on a structural autoregression framework suggest that fiscal policy can indeed be used for demand management, although the impact may be somewhat short-lived. This may reflect a number of factors, including the absence of creditconstrained economic agents, a high propensity to save among households, the use of quasifiscal measures not captured in budgetary data, a monetary focus on price stability, and leakages due to the openness of the economy. Notwithstanding the relatively short-lived impact, fiscal policy should still play a key stabilizing role in the current downturn given the considerable downside risks to growth and vast fiscal space in Singapore. To be effective, fiscal stimulus should be timely, well-targeted, significant, and prolonged. Moreover, it will be important to signal willingness to do more if needed to help allay uncertainty and bolster the impact of the fiscal measures. A fiscal stimulus package could include both revenue and expenditure measures. 


\section{REFERENCES}

Baxter, Marianne and Robert G. King, 1993, "Fiscal Policy in General Equilibrium," American Economic Review, Vol. 83(3), pp. 315-34, (June).

Bayoumi, Tamim, 2001, "The Morning After: Explaining the Slowdown in Growth in the 1990s," in Post-Bubble Blues-How Japan Responded to Asset Price Collapse ed. by T. Bayoumi and Charles Collyns (Washington: International Monetary Fund).

Blanchard, Olivier and Roberto Perotti, 2002, "An Empirical Characterization of the Dynamic Effects of Changes in Government Spending and Taxes on Output," Quarterly Journal of Economics 117, 1329-1368.

Blinder, Alan, 2004, "The Case against the Case against Discretionary Fiscal Policy," CEPS Working Paper No. 100 (New Jersey: Princeton University, Department of Economics, Center for Economic Policy Studies).

Botman Dennis, Phillip Karam, Douglas Laxton, and David Rose, 2007, DSGE Modeling at the Fund: Applications and Further Developments," IMF Working Paper 07/2007 (Washington: International Monetary Fund).

Corsetti, Giancarlo and Nouriel Roubini, 1996, "Budget Deficits, Public Sector Solvency and Political Biases in Fiscal Policy: A Case Study of Finland," Finnish Economic Papers, Vol. 9, Issue 1, (Spring), pp. 18-36.

De Castro Fernández, Francisco and Pablo Hernández de Cos, 2006, "The Economic Effects of Exogenous Fiscal Shocks in Spain: A SVAR Approach,” ECB Working Paper, Vol. 647 (Frankfurt: European Central Bank).

Giavazzi, Francesco and Marco Pagano, 1990, "Can Severe Fiscal Contractions be Expansionary? Tales of Two Small European Countries,” NBER Macro Annual 5, 75-111 (Cambridge, Massachusetts: National Bureau of Economic Research).

Giordano, Raffaela, Sandro Momigliano, Stefano Neri, and Roberto Perotti, 2007, "The Effects of Fiscal Policy in Italy: Evidence from a VAR Model," European Journal of Political Economy 23, 707-33.

Hemming Richard, Michael Kell, and Selma Mahfouz, 2002, "The Effectiveness of Fiscal Policy in Stimulating Economic Activity-A Review of the Literature," IMF Working Paper 02/208 (Washington: International Monetary Fund).

Heppke-Falk, Kirsten H., Jörn Tenhofen, and Guntram B. Wolff, 2006, “The Macroeconomic Effects of Exogenous Fiscal Policy Shocks in Germany: A Disaggregated SVAR Analysis," Discussion Paper, Series 1: Economic Studies, 41/2006, (Frankfurt: Deutsche Bundesbank, Research Centre). 
International Monetary Fund, 2008a, World Economic Outlook, April 2008: Housing and the Business Cycle, World Economic and Financial Surveys (Washington). , 2008b, World Economic Outlook, October 2008: Financial Stress, Downturns, and Recoveries, World Economic and Financial Surveys (Washington)

Johnson, David S., Jonathan A. Parker, and Nicholas S. Souleles, 2004, "The Response of Consumer Spending to the Randomized Income Tax Rebates of 2001," The Wharton School Working Paper, (New Jersey: Bureau of Labor Statistics, Princeton University).

Kuttner, Kenneth and Adam Posen, 2002, "Fiscal Policy Effectiveness in Japan," Journal of the Japanese and International Economies 16, 536-558

Linnemann, Ludger and Andreas Schabert, 2003, "Fiscal Policy in the New Neoclassical Synthesis," Journal of Money, Credit, and Banking, Vol. 35, No. 6, pp. 911-929.

Mühleisen, Martin, 2000, "Too much of a Good Thing? The Effectiveness of Fiscal Stimulus" in Post-Bubble Blues-How Japan Responded to Asset Price Collapse, ed. by T. Bayoumi and Charles Collyns (Washington: International Monetary Fund).

Perotti, Roberto, 2005, "Estimating the Effects of Fiscal Policy in OECD Countries," CEPR Discussion Paper 4842 (London: Centre for Economic Policy Research).

— , 2007, "In Search of the Transmission Mechanism of Fiscal Policy," NBER Working Paper 13143 (Cambridge, Massachusetts: National Bureau of Economic Research).

Posen, Adam, 1998, “Restoring Japan's Economic Growth,” (Washington: Institute for International Economics).

Shapiro, Matthew D. and Joel Slemrod, 2003, "Consumer Response to Tax Rebates," American Economic Review, Vol. 93 (1), 381-396 -, 2002, "Did the 2001 Tax Rebate Stimulate Spending? Evidence from Taxpayer Surveys," NBER Working Paper 9308 (Cambridge, Massachusetts: National Bureau of Economic Research). 